\title{
The Relationship between Effective Communication and Employee Retention of Operational Level Employees in Apparel industry in Sri Lanka
}

\author{
W.A.S.C Wijethunga ${ }^{1} \&$ P.A.B.H Amarathunga ${ }^{2}$ \\ Department of Business Management \\ Faculty of Business Studies \& Finance \\ Wayamba University of Sri Lanka \\ Kuliyapitiya \\ SRI LANKA \\ $\underline{\text { cs.sadun@gmail.com }}{ }^{1}, \underline{\text { buddhini@wyb.ac.lk }}$
}

\begin{abstract}
Human resource is the most valuable asset for every organization, which is generating unique competitive advantages. Retention of operational level employees has become a severe problem in apparel industry in Sri Lanka. The managements of most of the companies assume that weaknesses or deficiencies of internal communication system may be the reason for this unsolved turnover issue. Accordingly, primary objective of present research was analysis the relationship between effective communication (EC) and employee retention (ER) of operational level employees in Apparel industry, Sri Lanka. In this research 248 operational level employees were selected based on convenient judgment sampling method. Data was collected through a structured questionnaire and analyzed using SPSS. Effectiveness of the communication has been measured through supervisor support (SS), upward communication (UC) and quality of information (QI). Findings of the hypothesis 1 (There is a significant relationship between EC on ER) revealed that there is a strong positive relationship between EC and the retention intention of employees, hypothesis 2 (SS has significant relationship with ER) revealed that there is a strong positive relationship between SS and the retention intention of employees, hypothesis 3 (UC has significant relationship with ER) revealed that there is a weak positive relationship between UC and the retention intention of employees and hypothesis 4 (QI has significant relationship with ER) revealed that there is a moderate relationship between QI and the retention intention of employees. Based on the findings, SS has the highest positive relationship with ER. Demonstrating care about employees, providing counselling, strengthening connection between managers and employees and encouraging two-way communication are possible action for the company to improve communication. In order to establish healthy upward communication procedure within the organization, problem card system, employee satisfaction survey, and suggestion box systems can be introduced.
\end{abstract}

Keywords: Apparel Industry, Effective communication, Employee Retention, Operational level employee 


\section{INTRODUCTION}

Human resource is the most valuable asset for every organization, which is same as the foundation of a building. Skilled and talented employees are great value for every organization. According to Gberevbie, (2010) the human factor is very fundamental and has an important role for the success of the organization. That means it is very important in order to achieve the organizational goals and objectives. Physical capital resources, organizational capital resources and human capital resources are the basic three types of resources which provide competitive advantage for an organization (Liyanage \& Galhena, 2012). Barney and Wright, (1997) identified firm's people as the most important asset of a company (as cited in Liyanage \& Galhena, 2012).

Riordan et al., (2005) stated that, the human resource processes, skills, values, attitudes, knowledge, experiences strive to add economic values to the organizations and the industries (Gberevbie, 2010). As a result, it becomes very essential for organization in order to retain their workforce within the organization (Peterson, 2005, as cited in Gberevbie, 2010). As concerning the above arguments, the current researchers are able to argue that talented employees are great value for the companies.

Employee retention data reveals that $19.9 \%$ of Asian employees, 28.9\% Europe employees and 14\% USA employees intended that retention of current job is not an issue (Manhertz, 2011). When consider those statistics, it is clear that there is a problem of retaining skilled and talented employees within the organization. According to the previous studies based on the different financial and non-financial factors employees may tend to leave their organizations. It can be indicated those factors as cultural dimensions of the organization, supervisors' leadership styles, welfare facilities, communication, remunerations, working arrangements as the moderating factors to the employee attitudes on retaining or leaving the organizations (Dasgupta et al., 2012). These different factors may be influenced to the employee's attitudes and the behavior.

According to the Govaerts et al., (2011) the process of retention is very important for the future of the company in order to achieve the desired goals and objectives. Simply retention means, the effort of the employer to keep the most effective employees within the organization for achieving organizational objectives (Govaerts et al., 2011, as stated by Frank et al., 2004) and the previous researchers have identified that many organizational and employees' factors are affected to the employee retention (Govaerts et al., 2011). According to Bird et al, (2004) the organizational side factors which influence employee retention are meaningful work, opportunity for advancement, empowerment, new opportunities/challenges and Walker, (2011) has stated that compensation, recognition, appreciation on the works, opportunity to learn, positive relationship with the peers, good communication with the managers, rewards, leadership styles, and worklife balance can be influenced on 
employee retention (as cited in Govaerts et, al.,2011).

On the other hand, the factors at the employee level which affected to the employee retention have been identified in the previous studies as age, seniority, level of education (Govaerts et al., 2011). According Christiaensenet al., (2009) age has positive impact on the retention (Van Hamme, 2009) have found there is a positive impact of seniority on employee retention. But when it comes to the level of education results are not aligned. Some studies have identified there is a negative relationship between retention and the level of education (as cited by Govaerts et al., 2011).

Garment industry has an important place in Sri Lankan economy (Dheerasinghe, 2009). Sri Lankan garment industry has a strong commitment to welfare of its employees. It is guided by visionary slogan "Garments without Guilt" (Export Development Board, 2016). Garment industry is the largest export industry in Sri Lanka. Total export value of textiles and garments is 4,884 Dollar Million for the year 2016 (Central Bank Anuual Report, 2016). The industry provides more 300,000 direct employment opportunities and more and 600,000 indirect employment opportunities for peoples (Export Development Board , 2016). The major problem associates with the garment industry is problems in developing and maintaining the required manpower (Dheerasinghe, 2009).
In order to retain skilled and talented employees within the organization employee retention factors such as remuneration, welfare facilities, communication, leadership style, working conditions are important. Gberevbie, (2010) recommended several employee retention strategies for organizations as "humane treatment of employees through words of encouragement, informing employees on a regular basis on why certain actions are taken". Effective communication is much useful for above all tasks. Communication is much important function for every aspect of any organization. Drucker, 1954 explained that five functions of management; planning, organizing, staffing, leading and controlling are totally dependent on the communication (Conrad, 2014).

According to Wyatt, (2006) "Effective communication is the lifeblood of a successful organization" (as cited in Dasgupta et al., 2012). Because effective communication generates the relationships and moderates the attitudes and behavior of the employees. Interpersonal relationship with one another is very essential part of an organizational life and the sustainable success. So effective communication builds the relationships within the organization. Supportive communication is needed for getting maximum contribution from the employees. Because if there is a collaborative effort with the supervisor and the subordinates it can be overcome the desired goals and objectives successfully. 
Based on the empirical evidence most in every organizations use many of retention strategies in order to retain their employees and increase the retention ratio within the organization.

They focus on many factors to drive positively within the organization in order to retain the valuable employees. This research is going to be touched the retention of employees.

Voluntary turnover occurs when employee chooses to leave the job and involuntary turnover occurs when employer takes the displacing decision. Exit of substandard performers is considered as functional turnover and exit of effective performers is considered as dysfunctional turnover (Loquercio, 2006). Loquercio, (2006) identified family move, childbirth, serious illness or death are the causes for unavoidable turnover. Avoidable turnover is the manageable and important turnover which companies should be concerned.

Voluntary turnover is a major problem for companies in many Asian countries such as Hong Kong, South Korea, Malaysia, Singapore, and Taiwan and Sri Lanka (Rosse \& Miller 1984, Janssen et al., 1998, as cited in Liyanage \& Galhena, 2012). Accoring to Vandenberg, (1999) "Turnover occurs when an employee leaves a specific job or organization permanently and his/her services are no longer available" (Taylor et al, 2006). Turnover is "the termination of an individual's employment with a given company" (Tett \& Meyer, 1993).
There may be several factors that affected to employee turnover such as low level of job satisfaction, workload, job mismatch etc. Direct and indirect costs of turnover can be identified such as hiring cost, training cost, cost of temps etc. Those costs are affected to whole company in many ways.

High level employee turnover is costly for organizations. Cost may be financial and non-financial. Otherwise employee turnover or law employee retention have direct and indirect cost on organization (Mercer, 2004 as cited in Loquercio, 2006). Labor turnover cost can be classified as separation cost, replacement cost, training cost and hidden cost (Mathis \& Jackson, 2006, as cited in Liyanage \& Galhena, 2012). Merck and company, the pharmaceutical giant, has estimated that its turnover costs are between 150 $\%$ and $250 \%$ of the employee's annual salary (Mello, 2011, as cited in Iqbal, 2010).

High turnover ratio can be seriously hurdle productivity, quality, and profitability for any size firm (Iqbal, 2010). Tangible negative consequences of employee turnover are cost of recruitment, selection, training, production lost and intangible cost of employee turnover are moral impact, workload impact and team performance disruption (Achoui and Mansour, 2007, as cited in (Iqbal, 2010). Every time an employee quits form a company, a replacement must be recruited, selected, trained and permitted time on the job to gain experience (Samuel \& Chipunza, 2009). When productive 
employees quiet, organizations lose productivity, social capital and suffer customer defection (Sutherland, 2004, as cited in Samuel \& Chipunza, 2009). When consider about the employee composition of garment industry in Sri Lanka, operational category comprised $94 \%$ of the total workforce and $90 \%$ from them are females (Dheerasinghe, 2009). According to Dheerasinghe, (2009) average employee turnover per garment factory in Sri Lanka $60 \%$ per annum and leaving from industry $25 \%$ per year.

Actual cost of turnover is difficult to estimate. But most obvious expenses such as advertising cost, recruitment cost and supervisory time are indication of the turnover cost (Ampomah \& Cudjor, 2015). Furthermore, many researchers shown that high turnover might have negative effects on the profitability on organization if not managed properly (Wasmuth and Davis, 1993).

According to the previous researchers it has identified the employee retention situated in both organizational level and employee level (Govaerts et al., 2011). Birt et al., (2004) pointed out some organizational factors that are influenced to the employee retention are meaningful work, opportunities for career advancement, empowerment, responsibility, managerial integrity and new opportunities or challenges (as cited in Govaerts et al., 2011).

Moreover Walker, (2001) found seven factors that influence employee retention: compensation and appreciation of the performed work, provision of challenging work, chances to be promoted and to learn, invitational atmosphere within the organization, positive relations with colleagues, a healthy balance between the professional and personal life, and good communications (as cited in Govaerts et al., 2011).

\subsection{Hypotheses}

Four hypotheses tested at the present research can be mentioned as follow,

Hypothesis 1: There is a significant impact of EC on ER.

Hypothesis 2: SS has significant impact on ER.

Hypothesis 3: UC has significant impact on ER.

Hypothesis 4: QI has significant impact on ER.

\section{METHODS}

The total number of operational level employees within appeal industry in Sri Lanka was the population of the present research. Researcher has selected 260 OL employees as sample according as there is unknown population in the present research. Finally, researchers have selected 248 valid questionnaires for analyzing purpose. Samples have been selected from population by using Stratified Random Sampling technique. Data collection has been done through primary sources and secondary sources for current study.

The validity of the constructs and the reliability of the scales were tested using data from the current sample through SPSS version 20. Other descriptive analysis (mean, standard deviation) has been done for the scale type item related to the constructs. 
Correlation indicated the strength and the direction of a relationship between variables.

\section{RESULTS}

Pearson's correlation was applied to test the strength of association between independent variables and ER. Table 1 shows the results.

Table 1. Correlation Coefficients

\begin{tabular}{|c|l|r|r|r|r|}
\hline \multicolumn{2}{|c|}{} & EC & SS & UC & QI \\
\hline \multirow{2}{*}{ ER } & $\begin{array}{l}\text { Pearson } \\
\text { Correlation }\end{array}$ & $0.639^{* *}$ & $0.637^{* *}$ & $0.326^{* 8}$ & $0.546^{* *}$ \\
\cline { 2 - 6 } & $\begin{array}{l}\text { Sig. (2- } \\
\text { tailed) }\end{array}$ & 0.000 & 0.000 & 0.000 & 0.000 \\
\cline { 2 - 6 } & N & 248 & 248 & 248 & 248 \\
\hline
\end{tabular}

Hypothesis 1: There is a significant impact of EC on ER.

Pearson's correlation coefficient between EC and EC is 0.639 at 0.01 level of significance. It indicates strong positive relationship between $\mathrm{EC}$ and the retention intention of employees.

Hypothesis 2: SS has significant impact on ER.

Pearson's correlation coefficient between SS and ER is 0.637 at 0.01 level of significance. It indicates strong positive relationship between SS and the retention intention of employees.

Hypothesis 3: UC has significant impact on ER.

Pearson's correlation coefficient between $\mathrm{UC}$ and ER is 0.326 at 0.01 level of significance. It indicates weak positive relationship between UC and the retention intention of employees.

Hypothesis 4: QI has significant impact on ER.

Pearson's correlation coefficient between QI and ER is 0.546 at 0.01 level of significance. It indicates moderate relationship between QI and the retention intention of employees

Calculated correlation value between EC and ER indicates strong positive relationship $(\mathrm{R}=0.639, \mathrm{P}=0.000)$ between EC and the retention intention of OL employees in apparel industry. And there is a $45.7 \%$ positive influence $\left(\mathrm{r}^{2}=0.457, \mathrm{P}=\right.$ 0.000 ) of EC on operational level ER in the apparel industry.

\section{DISCUSSION}

Calculated correlation value between effective communication and employee retention indicates strong positive relationship $(\mathrm{R}=0.639, \mathrm{P}=$ $0.000)$ between effective communication and the retention intention of operational level employees in apparel industry. The previous literatures are proven that there is a significant relationship between effective communication and employee retention.

According to Hom, (1995) supervision, promotion process, fringe benefits as well as employee communication are negatively correlated with intent to leave and voluntary turnover (As cited in Taylor et al., 2006). Therefor positive correlation with the retention. According to the survey data, the 
current researcher argued that there is a positive relationship between communication and employee retention.

According to Moncarz et al., (2009) work's finding there was a moderate positively correlation between communication and employee retention. (Retention of non-managers $\mathrm{r}=0.320$ and retention of managers $r=0.443$ ). The current researcher has found the strong positive correlation between communication and the employee retention $(\mathrm{r}=0.639)$. Although there is positive correlation between communication and employee retention, the correlation value is greater than the Moncarz et al. (2009) study.

The independent variable, effective communication was comprised of three dimension and study has revealed the relationship between each dimension of effective communication and employee retention in the apparel industry.

Supervisor support has strong positive relationship $(\mathrm{R}=0.788, \mathrm{P}=0.000)$ between the retention intention of operational level employees. Upward communication has a weak positive relationship $(\mathrm{R}=0.326, \mathrm{P}=0.000)$ with the retention intention of operational level employees. Finally, quality of information has moderate positive relationship $(\mathrm{R}=0.546, \mathrm{P}=$ 0.000 ) with the retention intention of operational level employees.

The finding of correlation analysis is used to provide answer for second research question, "what is the most influencing variable of effective communication on employee retention with reference to the apparel industry. Supervisor support is the most influencing factor on employee retention with reference to the apparel industry. It indicates higher $\mathrm{R}$ value than other factors and indicates strong positive relationship $(\mathrm{R}=0.637)$ between the employee retention. Regression value also can be used to identify the most influencing factor on employee retention. $\mathrm{R}$ value 0.637 of supervisor support indicates that, there is $63.7 \%$ positive influence of supervisor support on operational level employee retention in the apparel industry.

\section{CONCLUSION}

ER is one of the primary parameters to measure the health of many organizations. When employees leave an organization, they take along with them knowledge capital, relationships and investments. Talented employers never undermine the importance of retaining the best talent. Business strategies in general and HR policies and practices in particular must be framed in such a way that they ensure retention of key performers. Although there are so many factors that affected to ER such as compensation \& rewards, job security, training \& developments, work environment and organization justice etc., current study has focused only on effectiveness of communication.

Based on the results it has been identified that there is a positive significant impact of EC on operational level ER. The researcher recommended that there should be a very strong internal communication system within the organization. The 
SS is very much important to build a strong relationship and establish an EC bridge between superior and the employees. Therefore, company should take action to improve SS. Demonstrating care about employees, providing help when individual have problems, strengthening connection between managers and employees, getting outside of the office, and encouraging two-way communication are possible action for the company to improve communication. In addition to that, it should be strengthening the open-door policy, where managers can give the fair attention on each and every problem related to the job and work environment. UC is much important to retain the current employees within the organization. In order to establish healthy upward communication procedure within the organization, problem card system, employee satisfaction survey, and suggestion box systems can be introduced. QI is very special factor to establish effective communication within an organization. Company is able to improve QI by making objectives and goals public, making internal knowledge and documents easily available, creating an internal language, and scheduling status meetings regular basic. Also using online tools instead of meeting and training peoples in the language of sharing are another effective method to improve QI.

\section{REFERENCES}

Achoui, M. and Mansour, M (2007), "Employee Turnover and Retention Strategies: Evidence from Saudi Companies",
International Review of Business

Research Papers, 3(3), pp. 1-16.

Ampomah, P., \& Cudjor, S. K. (2015).

The Effect of Employee Turnover on Organizations (Case Study of Electricity Company of Ghana, Cape Coast). Asian Journal of Social Sciences and Management Studies, 2(1), pp. 21-24.

Barney, J. B. \& Wright, P. M. (1997). On becoming a strategic partner: The role of human resources in gaining competitive advantage (CAHRS Working Paper \#97-09). Ithaca, NY: Cornell University, School of Industrial and Labor Relations, Center for Advanced Human Resource Studies.

Conrad, D. (2014). Workplace Communication Problems: Inquiries by Employees and Applicable Solutions. Journal of Business Studies Quarterly, 5(4), pp. 105-116.

Dheerasinghe, R. (2009). Garment Industry in Sri Lanka Challenges, Prospects and Strategies. Staff studies.

Gberevbie, D. E. (2010). Organizational retention strategies and employee performance of Zenith Bank in Nigeria. African Journal of Economic and Management Studies, 1(1), pp.61-74. 
Govaerts, N., Kyndt, E., Dochy, F., \& Baert, H. (2011). Influence of learning and working climateon the retention of talented employees. Journal of Workplace Learning, 23(1), pp.35-55.

Hom, P.W. (1995). Employee turnover. Cincinnati, $\mathrm{OH}$ : SouthWestern.

Iqbal, A. (2010). Employee Turnover: Causes, Consequences and Retention Strategies in the Saudi Organizations. The Business Review, Cambridge, 16(2), pp. 275-281.

Liyanage, D., \& Galhena, B. (2012). Determinants of Turnover Intention of Sewing Machine Operators: Case from leading Apparel Company. Kelaniya Journal of Management, pp. 107123.

Loquercio, D. (2006). Turnover and retention.

Manhertz, H. J. (2011). How to Keep Your Best Employees in Any Market. Worldwide Trends in Employee Retention.

Moncarz, E., Zhao, J., \& Kay, C. (2009). An exploratory study of US lodging properties' organizational practices on employee turnover and retention. International Journal of
Contemporary Hospitality

Management, pp. 438-458.

Riordan, C. M., Vandenberg, R.J. and Richardson, H.A. (2005). 'Employee involvement climate and organizational effectiveness', Human Resource Management, 44, 471-488.

Samuel, M. O., \& Chipunza, C. (2009). Employee retention and turnover: Using motivational variables as a panacea. African Journal of Business Management, 3(8), pp. 410-415.

Taylor, L. J., Murphy, B., \& Price, W. (2006). Goldratt's thinking process applied to employee retention. Business Process Management Journal, 12(5), pp.646-670.

Tett, R. P., \& Meyer, J. P. (1993). Job satisfaction, organizational commitment, turnover intention, and turnover: Path analyses based on meta-analytic findings. Personnel Psychology, 46(2), 259-293.

Wasmuth WJ, Davis S W (1993). "Managing employee turnover: why employees leave", The Cornell Headquarter, pp.11-18. 